\section{Rootstock Effects on Growth and Quality of 'Gala' Apples}

\author{
Yahya K. Al-Hinai and Teryl R. Roper \\ Department of Horticulture, University of Wisconsin-Madison, Madison, \\ WI 53706
}

Additional index words. crop load, yield efficiency, TCA, light interception, flesh firmness, SSC

\begin{abstract}
The effect of rootstock on apple size is not clear due to inconsistent results of published studies. This study was conducted over 3 years at the Peninsular Agricultural Research Station near Sturgeon Bay, WI on 6-year-old 'Gala' apple trees (Malus domestica Borkh) grafted on Malling 26 (M.26), Ottawa 3, M.9 Pajam 1, and Vineland (V)-605 rootstocks. Fruit diameter was measured weekly. Fruit weight and volume were estimated by a quadratic regression of weekly measurements. Fruit weight was positively correlated with fruit volume. Rootstock had no effect on fruit growth and final size even with the removal of crop load effects. Crop load was a highly significant covariate for fruit size, but canopy light interception and seed count were not. Trees on M.26 EMLA had slightly higher yield in 2000 but rootstock did not affect yield efficiency any year. Rootstock had no influence on fruit quality attributes during 2001; however, in 2002, fruit obtained from trees on Pajam1 tended to be less firm. Generally, apple fruit size was influenced by crop load and other factors, but not by rootstock.
\end{abstract}

Commercial apple growers have an economic incentive to grow large fruit while maintaining yield. Since rootstocks are an important component of apple production systems, positive effects of rootstock on fruit size would be beneficial. Apple rootstocks influence potential tree density, precocity, and cropping efficiency (NC140, 1987, 1996). Fruit size is one of the most important determinants of price (Bergh, 1985). Since many factors can influence fruit size including crop load (Bergh, 1985; Palmer et al., 1997), seed count and inflorescence position (Denne, 1963), light interception (Robinson et al., 1983), temperature (Warrington et al., 1999), thinning (Lakso et al., 1995), training system (Ferree and Palmer, 1982), and rootstock (Autio, 1991; Autio et al., 2003), it is difficult to study the effects of one factor, such as rootstock, without taking into account other potential sources of variation.

A number of studies have reported that rootstock influences aspects of fruit quality such as ripening and storability (Lord et al., 1985), mineral composition (Drake et al., 1988), size (Marini et al., 2002) and firmness (Brown and Wolfe, 1992). However, the effects of most of the rootstocks studied were not consistent from site to site and varied over time.

To evaluate the full commercial potential of a particular apple rootstock, it is important to take into account other sources of variability and to evaluate rootstock effects on fruit size for specific regions or cultivars. Autio (1991) documented that fruit size of 'Starkspur Supreme Delicious' planted in Massachusetts was dramatically affected by rootstock, even with removal of crop load effects. However, Hirst

Received for publication 20 Oct. 2003. Accepted for publication 1 Mar. 2004. This research was supported by the College of Agricultural and Life Sciences through regional research funds.

${ }^{1}$ To whom requests for reprints should be addressed; e-mail trroper@wisc.edu. and Flowers (2000) found no effect of rootstock on fruit growth rate or final fruit size of 'Gala' apples grown in Indiana.

This study was carried out to investigate, over 3 years, the effects of four rootstocks on 'Gala' apple fruit growth, size and quality taking into account multiple potential sources of variation.

\section{Materials and Methods}

This study was conducted for 3 years at the Peninsular Agricultural Research Station near Sturgeon Bay, WI on a Longrie sandy loam soil (coarse, loamy, mixed, frigid, Entic Haplorthod), $\mathrm{pH} \approx 7$ with $4 \%$ organic matter. The orchard was planted in 1994 with trees grafted to the same scion (TRECO Red Gala \#42) in the same nursery using the same parent material. Thirty scions on four rootstocks [eight on each of M.26 EMLA (M.16 x M.9) and V605-1 (M.9 open pollinated), and seven on each of Ottawa 3 (Robin x M.9) and Pajam 1 (M.9 clone)] were used. The experimental design was a nested factorial design with repeated measures ( 4 rootstocks $\times 7$ or 8 trees per rootstock $\times 5$ limbs per tree $\times 3$ fruit per limb measured at weekly intervals). The study was repeated on the same trees for three years.

The orchard was maintained according to protocols established for the existing NC-140 regional research project. Trees were trained to a central leader system. Alleys between rows were planted to a grass sod and a 2-m-wide weed-free area within the tree row was maintained with glyphosate herbicide. Trees were chemically thinned each year with $0.56 \mathrm{~kg} / \mathrm{ha}$ Carbaryl in early to mid-June when king fruit were about 10 mm in diameter. In 2003, 50 ppm benzyladenine (Accel, Valent Biosciences, Libertyville, Ill.) was tankmixed with the Carbaryl.

Each year at full bloom five different branches per tree were randomly tagged except for the first year (2000) where three or six branches were selected instead depending on the availability of experimental limbs. For example, six branches were tagged on V-605-1 because trees were vigorous compared to trees on Ottawa 3. Because fruitlet size depends on its position in a cluster, the king fruit in a cluster usually develops faster and is larger than lateral fruitlets (Goldwin and Ermen, 1989). In this study, king and lateral fruitlets were randomly selected at full bloom to reflect commercial harvest. Three individual flowers were tagged at the base, middle and outside of each tagged limb.

In 2000, 2001, and 2002 fruit growth was measured weekly with a digital caliper beginning at four weeks after full bloom through harvest. Length and width were taken for each tagged fruit. Fruit volume was measured by liquid displacement along with length, diameter, and fresh weight of three fruit per tree and six trees per rootstock nine times during the season. Quadratic regression was then used to calculate fruit volume and weight during fruit development. At harvest, tagged fruit size was measured and the total crop from each tree was weighed and counted. Trunk cross-sectional-area (TCA) was calculated from trunk diameter measurements. Crop load was calculated as number of fruit per square centimeter TCA. Subsamples of 50 apples from each tree were randomly selected at harvest for individual fruit size measurements of length, diameter, weight, and volume. Flesh firmness was determined with an Effegi penetrometer(11.1-mm-diameter probe; Effegi, Alfonsine, Italy) and soluble solids concentration (SSC) was measured using a hand-held Atago refractometer (Atago Co. Ltd., Tokyo, Japan). In 2000 at harvest, seeds were counted in 300 fruit.

Canopy light interception [1 - (PAR below canopy/PAR above canopy)] was calculated from records of above canopy incident irradiance and of tree light transmission during mid July 2001 at dawn using a canopy analyzer (LAI2000; LI-COR, Lincoln, Neb.). For simplicity, light measurements were collected at three different positions on each tagged limb for three randomly selected limbs per tree and five trees per rootstock along with leaf samples to use specific leaf area (SLA) as a proxy for intercepted light at fruit positions (Ellsworth and Reisch, 1993). Fifteen fully expanded spur and shoot leaves were sampled along the limb to calculate SLA and a regression analysis of logarithmic transformed data was used to estimate canopy light interception for all tagged fruit.

All data were subjected to analysis of variance using the SAS Mixed procedure and linear regression analysis using the SAS Regression procedure (SAS Institute., Inc., Cary, N.C.). Data for fruit growth were analyzed with weeks as repeated measures. Covariate analysis was used where it improved the efficiency of analysis, such as using crop load as a covariate for fruit size. All means were separated by Fisher's protected $t$ test using the Proc Mixed models procedure of SAS, $P \leq 0.05$.

\section{Results and Discussion}

Generally, rootstocks had no influence on 'Gala' final fruit size measured by indi- 
Table 1. Effects of rootstock on crop load, yield, yield efficiency, fruit number, and fruit size of 'Gala' apples $(n=4)$.

\begin{tabular}{|c|c|c|c|c|c|c|}
\hline Rootstock & $\begin{array}{l}\text { Crop load } \\
\text { (no. fruit/ } \\
\mathrm{cm}^{2} \text { TCA) }\end{array}$ & $\begin{array}{c}\text { Yield } \\
\text { (kg/tree) }\end{array}$ & $\begin{array}{c}\text { Yield } \\
\text { efficiency } \\
\left(\mathrm{kg} \cdot \mathrm{cm}^{-2} \mathrm{TCA}\right)\end{array}$ & $\begin{array}{c}\text { Fruit } \\
\text { (no./tree) }\end{array}$ & $\begin{array}{l}\text { Fruit } \\
\text { size } \\
(\mathrm{g})\end{array}$ & $\begin{array}{c}\text { Fruit size } \\
\text { adjusted for } \\
\text { crop load }(\mathrm{g})\end{array}$ \\
\hline \multicolumn{7}{|l|}{2000} \\
\hline M.26 EMLA & 7.0 & $54.8 \mathrm{a}^{\mathrm{z}}$ & 1.0 & $366 \mathrm{a}$ & 149 & 150 \\
\hline Ottawa-3 & 6.0 & $28.8 \mathrm{~b}$ & 0.9 & $201 \mathrm{~b}$ & 148 & 146 \\
\hline Pajam-1 & 7.9 & $40.6 \mathrm{ab}$ & 1.1 & $281 \mathrm{ab}$ & 144 & 147 \\
\hline V-605-1 & 5.6 & $36.8 \mathrm{~b}$ & 0.8 & $255 \mathrm{~b}$ & 145 & 143 \\
\hline$P$ value & 0.22 & 0.009 & 0.1 & 0.02 & 0.81 & 0.56 \\
\hline \multicolumn{7}{|l|}{2001} \\
\hline M.26 EMLA & 6.1 & 53.2 & 0.9 & 358 & 150 & 149 \\
\hline Ottawa-3 & 7.6 & 40.1 & 1.0 & 314 & 142 & 145 \\
\hline Pajam-1 & 7.4 & 43.5 & 1.0 & 319 & 143 & 145 \\
\hline V-605-1 & 5.4 & 49.9 & 0.8 & 315 & 146 & 143 \\
\hline$P$ value & 0.13 & 0.22 & 0.42 & 0.84 & 0.50 & 0.67 \\
\hline \multicolumn{7}{|l|}{2002} \\
\hline M.26 EMLA & 8.5 & 80.6 & 1.3 & 542 & 146 & 141 \\
\hline Ottawa-3 & 10.7 & 61.4 & 1.5 & 453 & 143 & 145 \\
\hline Pajam-1 & 10.7 & 68.2 & 1.5 & 480 & 144 & 146 \\
\hline V-605-1 & 9.4 & 76.4 & 1.2 & 576 & 140 & 138 \\
\hline$P$ value & 0.10 & 0.29 & 0.08 & 0.32 & 0.74 & 0.23 \\
\hline
\end{tabular}

${ }^{2}$ Mean values with different letters within columns and years are significantly different at $P \leq 0.05$ as determined by Fisher's protected $t$ test using the Proc Mixed models procedure of SAS.

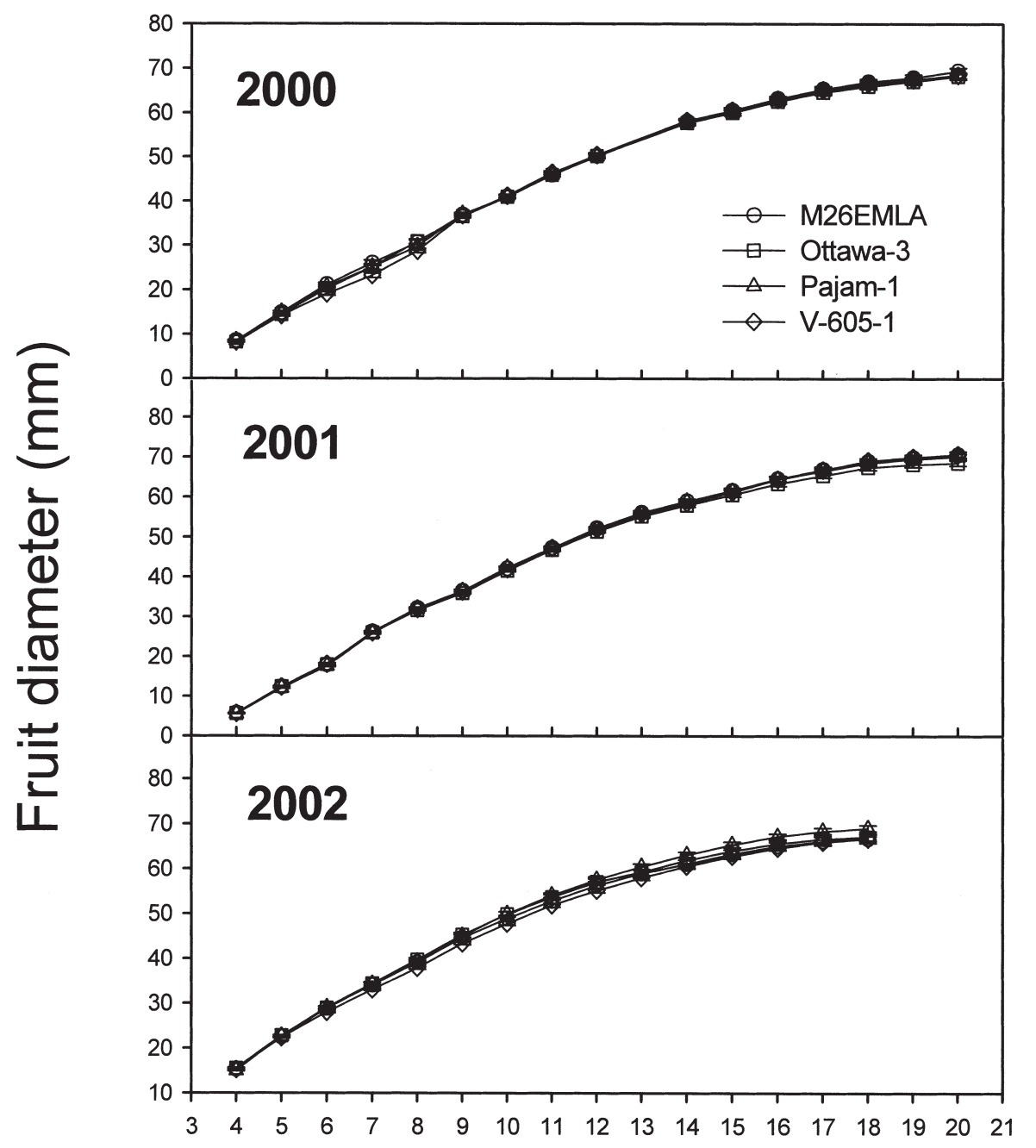

\section{Weeks after full bloom}

Fig. 1. Effects of rootstock on weekly growth of 'Gala' apples measured by fruit diameter (mm). Scions were grown on M.26 EMLA, Ottawa-3, Pajam-1, and V-605-1 rootstocks at the Peninsular Agricultural Research Station near Sturgeon Bay, WI. Values are adjusted for crop load as a covariate. Points are LS means \pm standard error of the mean. vidual fruit weight over 3 years (Table 1). The inconsistency of previous studies of rootstock effects on fruit size was partly due to ignoring other contributing factors in fruit size development, including crop load, tree size, light interception, and seed count. It is difficult to verify the effects of one factor such as rootstock without taking into account other potential sources of variability that might alter the overall relationship between rootstock and fruit size. Crop load (fruit number/ $\mathrm{cm}^{2} \mathrm{TCA}$ ) was a significant covariate for fruit size $(P$ $<0.0001$ ) for all years; however, other factors such as seed count and canopy light interception were not ( $r^{2}=0.03$ and 0.012 , respectively). Palmer et al. (1997) determined that crop load had a significant influence on fruit size. They documented that heavy crop loads produce smaller fruit compared to light cropping. Our data confirmed this association between crop load and fruit size. Because of this association between crop load and fruit size, fruit size was adjusted for crop load.

Seed count can affect apple fruit size (Denne, 1963). However, analysis of 300 mature 'Gala' fruit during 2000 did not show any correlation between fruit size and seed number $\left(r^{2}=0.03\right)$. There was no effect of rootstock on 'Gala' seed number. The range of seed number varied from 0 to 13 seeds for fruit of similar size, indicating that seed count was not a covariate for fruit size in this study. These data suggest that 'Gala' fruit may be partially parthenocarpic. However, fruit with no seeds tended to be smaller than fruit with at least one seed $(P=0.01)$.

Light can vary markedly within a tree canopy yet is a key environmental factor that affects fruit growth. Light has been shown to influence fruit size and quality, including red pigmentation, soluble solids concentration, and fruit weight (Robinson et al., 1983). Trees in this study were trained to a central axe system, well pruned and were not overly crowded so leaf area index and transmission of light through the canopy were similar for all treatments. Thus, light interception was not a significant covariate.

Generally, rootstock did not affect fruit growth as measured by diameter over the season for 3 years, even with the removal of crop load effects (Fig. 1). Weight and volume (measured over time) of 'Gala' apples were highly correlated $\left(r^{2}=0.99\right)$. Because of this association, either metric could be used to assess fruit size. The growth curves for fruit diameter were very similar to those obtained by Denne (1960) for 'Cox's Orange Pippin' apples. Fruit growth was not influenced by the selected rootstocks perhaps because all tested rootstocks act similarly in Wisconsin. Over 27 planting sites, 'Starkspur Supreme Delicious' fruit from trees on M.27 EMLA were smaller than from trees on M.9 EMLA or M.26 EMLA rootstocks (NC-140, 1991). Conversely, in Massachusetts, Autio (1991) reported that fruit from trees on M.27 EMLA rootstock were similar in size to those from trees on M.26 EMLA and M.9 EMLA rootstocks. Marini et al. (2002) found inconsistent effects of rootstock on fruit size across different 
Table 2. Effects of rootstock on mature 'Gala' fruit flesh firmness and soluble solids concentration (SSC) over two growing seasons at the Peninsular Agricultural Research Station near Sturgeon Bay, Wis.

\begin{tabular}{|c|c|c|c|c|}
\hline \multirow[b]{2}{*}{ Rootstock } & \multicolumn{2}{|c|}{$\begin{array}{l}\text { Firmness } \\
\text { (Newtons) }\end{array}$} & \multicolumn{2}{|c|}{$\begin{array}{l}\text { Sugar content } \\
\left({ }^{\circ} \text { Brix }\right)\end{array}$} \\
\hline & 2001 & 2002 & 2001 & 2002 \\
\hline M.26 EMLA & 72.4 & $77.7 \mathrm{a}^{2}$ & 11.8 & $13.7 \mathrm{ab}$ \\
\hline Ottawa-3 & 73.8 & $77.7 \mathrm{a}$ & 11.6 & $14.2 \mathrm{a}$ \\
\hline Pajam-1 & 69.3 & $71.5 \mathrm{~b}$ & 11.7 & $13.0 \mathrm{bc}$ \\
\hline V-605-1 & 71.5 & $76.8 \mathrm{a}$ & 11.6 & $12.8 \mathrm{c}$ \\
\hline$P$ value & 0.15 & 0.01 & 0.54 & 0.001 \\
\hline
\end{tabular}

${ }^{2}$ Mean values with different letters within columns and years are significantly different at $P \leq 0.05$ as determined by Fisher's protected $t$ test using the Proc Mixed models procedure of SAS.

production areas. Thus, rootstock might have an influence on fruit size, but this influence may differ from site to site, year to year, and between cultivars.

Generally, rootstock had no effects on fruit size of 'Gala' scions grown in a temperate climate in northeast Wisconsin even when effects of crop load were removed, suggesting that factors other than rootstock are more important in producing larger fruit. Hirst and Flowers (2000) documented similar results for 'Gala' apples in Indiana. Although rootstock effects on fruit size have been documented (Autio, 1991; Autio et al., 2003), results were not always consistent and varied over time (Lord et al., 1985), across geographical regions (Autio et al, 2003; NC-140, 1996), and between cultivars (Autio et al., 2003; Wertheim, 1989). Autio et al. (2003) found that 'Cortland', 'McIntoch', and 'Pioneer Mac' apple size was affected by rootstock, but not 'Gala'.

Except in 2000, rootstock had no influence on yield. However, all trees were chemically thinned after petal fall to achieve similar crop loads. Trees on M.26 EMLA had slightly higher yields in 2000 compared to trees on Ottawa-3 and V-605-1 rootstocks. Scions on Pajam-1 were intermediate. Volz (1988) found strong and positive relationships between fruit numbers per tree and total yield, and the total weight of fruit. Because yield was positively correlated with fruit number, trees on M.26 EMLA had more fruit, probably because they had more bearing surface compared to trees on other rootstocks (Hirst and Ferree, 1996).

Yield efficiency was not significantly different any year in this trial perhaps because all tested rootstocks were M.9 clones or had M.9 as a parent, which provided little genetic diversity. Webster and Hollands (1999) working with 'Cox's Orange Pippin' grown on 24 selections (clones) of M.9 showed that none of the clones had any consistent effect on the precocity of flowering, the numbers of floral buds produced by the trees, or the efficiency of fruit set.

Flesh firmness and SSC were not affected by rootstock in 2001 (Table 2). A similar result was found by Brown and Wolfe (1992). They showed that fruit from 'Starkspur Supreme Delicious' on M.26 EMLA and Ottawa-3 rootstocks were similar in flesh firmness and SSC. In 2002, fruit from trees on Pajam-1 were less firm than fruit from other rootstocks. Harker et al. (1997) showed that firmness depends on cell size, cell wall thickness and strength, and cell shape and packing (number per volume). In this study, a significant relationship between fruit weight and flesh firmness was evident because variation in fruit size within 'Gala' in Wisconsin is due to difference in cell size rather than cell number, although no correlation between cell size and firmness was evident (Al-Hinai, 2003). Generally, the effect of rootstock on firmness is minor and varies from site to site (Autio, 2003). Because of the inconsistent results obtained for the two years, the effects of rootstock on fruit quality, if any, are not clear. Other factors, such as thinning (Johnson, 1992) and light exposure (Robinson et al. 1983), have been found to be far more important in fruit quality rather than rootstock.

In conclusion, apple rootstock had no effects on 'Gala' fruit growth, final size, or yield efficiency under Wisconsin's climate even with the removal of crop load effects. To study the effects of a particular factor, such as rootstock, on fruit size and quality, it is critical to take into account other potential sources of variability. The inconsistent results of rootstock effects on fruit quality did not provide a clear understanding of how rootstock affects fruit firmness or SSC. Thus, apple growers should make rootstock decisions based on size control, disease resistance and yield efficiency, but not effects on fruit size.

\section{Literature Cited}

Al-Hinai, Y.K. 2003. Rootstock effects on growth, quality, cell number and cell size of 'Gala' apple fruit. PhD diss. Univ. Wis.-Madison.

Autio, W.R. 1991. Rootstocks affect ripening and other qualities of 'Delicious' apples. J. Amer. Soc. Hort. Sci. 116:378-382.

Autio, W.R., J.R. Schupp, C.G. Embree, and R.E. Moran. 2003. Early performance of 'Cortland', 'Macoun', 'McIntoch', and 'Pioneer Mac' apple trees on various rootstocks in Maine, Massachusetts, and Nova Scotia. J. Amer. Pomol. Soc. 57:7-14.

Bergh, O. 1985. Effect of the previous crop on the cortical cell number of Malus domestica cv. Starking Delicious apple flower primordial, flower and fruit. S. Afr. J. Plant Soil 2:191-196.

Brown, G.R. and D. Wolfe. 1992. Rootstock affects maturity of 'Starkspur Supreme Delicious' apples. HortScience 27:76.

Denne, M.P. 1960. The growth of apple fruitlets and the effect of early thinning on fruit development. Ann. Bot. 24:397-406.

Denne, M.P. 1963. Fruit development and some tree factors affecting it. N.Z. J. Bot. 1:265-294.

Drake, S.R., F.E. Larsen, J.K. Fellman, and S.S. Higgins. 1988. Maturity, storage quality, carbohydrate, and mineral content of 'Goldspur' apples as influenced by rootstock. J. Amer. Soc. Hort. Sci. 113:949-952.

Ellsworth, D.S. and P.B. Reisch. 1993. Canopy structure and vertical patterns of photosynthesis and related leaf traits in a deciduous forest. Oecologia 96:169-178

Ferree, D.C. and J.W. Palmer. 1982. Effect of spur defoliation and ringing during bloom on fruiting, fruit mineral level, and net photosynthesis of 'Golden Delicious' apple. J. Amer. Soc. Hort. Sci. 107:1182-1186.

Goldwin, G.K. and H. Ermen. 1989. Tree to tree variability in the yield of apple Malus pumila, cv. Cox's Orange Pippin. J. Hort. Sci. 64:259-264.

Harker, F.R., R.J. Redgwell, I.C. Hallett, and S.H. Murray. 1997. Texture of fresh fruit. Hort. Rev. 20:121-224.

Hirst, P.M. and D.C. Ferree. 1996. Effects of rootstock on bud development and flower formation of 'Starkspur Supreme Delicious' apple. Fruit Var. J. 50:25-34.

Hirst, P.M. and R.R. Flowers. 2000. Rootstock effects on growth and cell size of 'Gala' apple fruit. Acta Hort. 517:189-194.

Johnson, D.S. 1992. The effect of flower and fruit thinning on the firmness of 'Cox's Orange Pippin' apples at harvest and after storage. J. Hort. Sci. 67:95-101.

Lakso, A.N., L.C. Grappadelli, J. Barnard, and M.C. Goffinet. 1995. An expolinear model of the growth pattern of apple fruit. J. Hort. Sci. 70:389-397.

Lord, W.J., D.W. Greene, R.A. Damon, Jr., and J.H. Baker. 1985. Effects of stem piece and rootstock combinations on growth, leaf mineral concentrations, yield, and fruit quality of 'Empire' apple trees. J. Amer. Soc. Hort. Sci. 110:422-425.

Marini, R.P, J.A. Barden, J.A. Cline, R.L. Perry, and T. Robinson. 2002. Effect of apple rootstocks on average 'Gala' fruit weight at four locations after adjusting for crop load. J. Amer. Soc. Hort. Sci. 127:749-753.

NC-140. 1987. Growth and production of 'Starkspur Supreme Delicious' on 9 rootstocks in the NC-140 cooperative planting. Fruit Var. J. 41:31-39.

NC-140. 1991. Performance of 'Starkspur Supreme Delicious' apple on 9 rootstocks over 10 years in the NC-140 cooperative planting. Fruit Var. J. 45:192-199.

NC-140. 1996. Performance of the NC-140 cooperative apple rootstock planting: I. Survival, tree size, yield and fruit size. Fruit Var. J. 50:6-11.

Palmer, J.W., R. Giuliani, and H.M. Adams. 1997. Effect of crop load on fruiting and leaf photosynthesis of 'Braeburn'/M.26 apple trees. Tree Physiol. 17:741-746.

Robinson, T.L., E.J. Seeley, and B.H. Barritt. 1983. Effect of light environment and spur age on 'Delicious' apple fruit size and quality. J. Amer. Soc. Hort. Sci. 108:855-861.

Volz, R.K. 1988. Regulation and estimation of crop load on 'Gala' apple trees. N.Z. J. Expt. Agr. 16:47-53.

Warrington, I.J., T.A. Fulton, E.A. Halligan, and H.N. De Silva. 1999. Apple fruit growth and maturity are affected by early season temperatures. J. Amer. Soc. Hort. Sci. 124:468-477.

Webster, A.D. and M. Hollands. 1999. Orchard comparisions of 'Cox's Orange Pippin' grown on selections of the apple rootstock M.9. J. Hort. Sci. Biotechnol. 74:513-521.

Wertheim, S.J. 1989. Preliminary results of trials with dwarfing apple and pear rootstocks. Acta Hort. 243:59-70. 